\title{
Comparative Effect of ACTH and Related Peptides on Proliferation and Growth of Rat Adrenal Gland
}

\author{
Claudimara Ferini Pacicco Lotfi ${ }^{\star}$ and Pedro O. R. de Mendonca \\ Department of Anatomy, Institute of Biomedical Science, University of São Paulo, São Paulo, Brazil
}

Pro-opiomelanocortin (POMC) is a polypeptide precursor known to yield biologically active peptides related to a range of functions. These active peptides include the adrenocorticotropic hormone (ACTH), which is essential for maintenance of adrenal growth and steroidogenesis, and the alpha-melanocyte stimulation hormone, which plays a key role in energy homeostasis. However, the role of the highly conserved $\mathrm{N}$-terminal region of POMC peptide fragments has begun to be unraveled only recently. Here, we review the cascade of events involved in regulation of proliferation and growth of murine adrenal cortex triggered by ACTH and other POMC-derived peptides. Key findings regarding signaling pathways and modulation of genes and proteins required for the regulation

OPEN ACCESS

Edited by:

Nicole Gallo-Payet,

University of Sherbrooke, Canada

Reviewed by:

Tullio Florio,

Università degli Studi di Genova, Italy

Gavin P. Vinson,

Queen Mary University of

London, UK

*Correspondence:

Claudimara Ferini Pacicco Lotfi clotfi@usp.br

Specialty section:

This article was submitted

to Neuroendocrine Science,

a section of the journal

Frontiers in Endocrinology

Received: 27 February 2016

Accepted: 25 April 2016

Published: 09 May 2016

Citation:

Lotfi CFP and de Mendonca POR (2016) Comparative Effect of ACTH and Related Peptides on Proliferation and Growth of Rat Adrenal Gland.

Front. Endocrinol. 7:39.

doi: 10.3389/fendo.2016.00039 of adrenal growth are summarized. We have outlined the known mechanisms as well as future challenges for research on the regulation of adrenal proliferation and growth triggered by these peptides.

Keywords: adrenal growth, ACTH, N-POMC, proliferation, cell cycle

\section{INTRODUCTION}

The primary function of the adrenal cortex is to produce steroids. Each zone of the adrenal cortex synthesizes different steroids in response to endocrine and paracrine stimuli. Adrenal function and maintenance of adrenal size are associated with regulation of adrenocortical growth, a topic that has been covered by other studies $(1,2)$. This review summarizes our understanding of growth regulators of the murine adrenal and highlights the action of adrenocorticotropic hormone (ACTH) and $\mathrm{N}$-terminal peptides of pro-opiomelanocortin (N-POMC) in the control of proliferation and maintenance of the adrenal cortex.

\section{PRO-OPIOMELANOCORTIN IN MURINE}

Pomc is a gene that belongs to the opioid/orphanin family. It is a highly conserved gene found from agnathan fish to mammals (3). In murines, this gene encodes a prohormone of 235 amino acids produced mainly by corticotropic cells in the pituitary gland. Post-translational processing at specific sites results in production of various smaller peptides, including peptide hormones with a range of physiological functions (Figure 1). In addition to the pituitary gland, POMC peptides are found in a diverse range of tissues, including the hypothalamus, skin, lung, gut, and pancreas (4). POMC transcripts found in these tissues are not full length, resulting in low levels of protein (5), and its function is not clear. POMC peptides in the circulation are derived mainly from the pituitary, and thus, the peptides produced in peripheral tissues act in an autocrine or paracrine way. The enzymes 


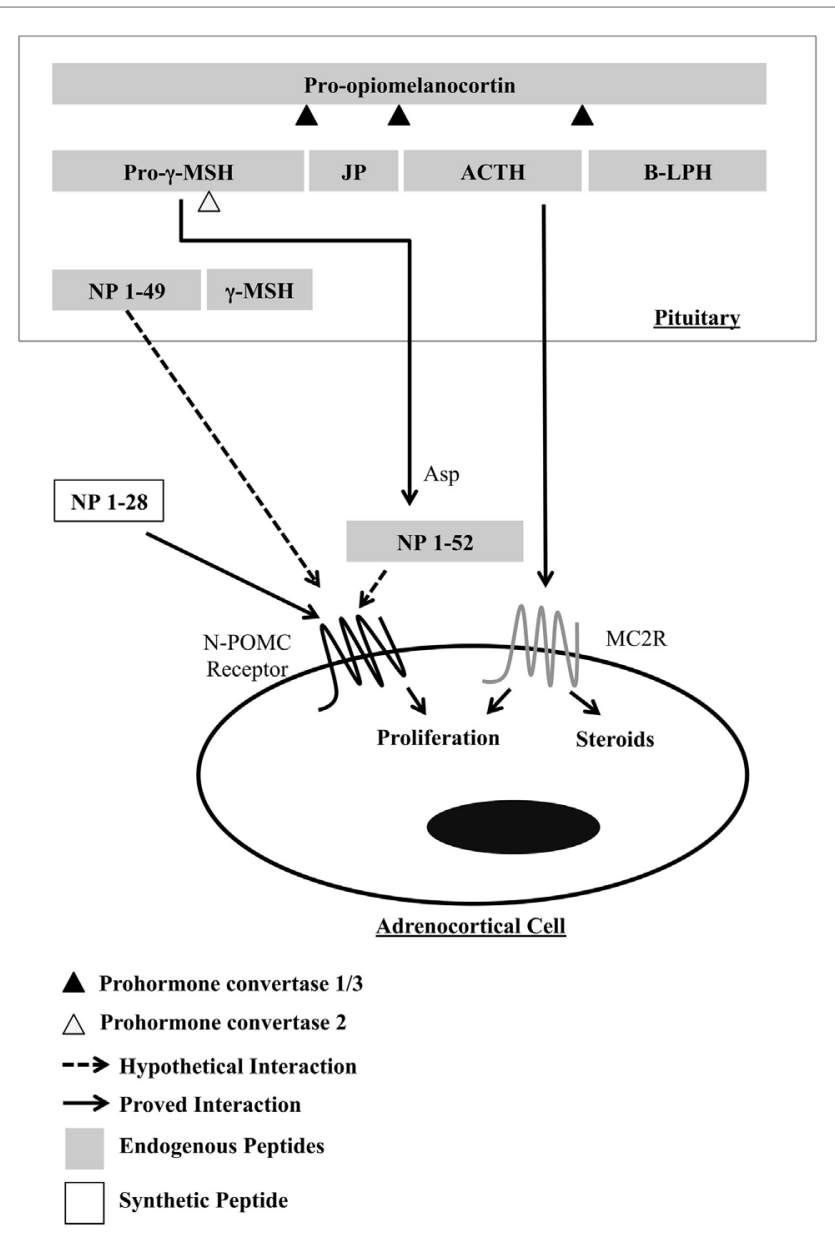

FIGURE 1 | Processing of POMC in the murine pituitary, highlighting the resulting peptides that act in the proliferation of adrenocortical cells. $\gamma$-MSH, gamma-melanocyte-stimulating hormone; JP, joining peptide; $\mathrm{ACTH}$, adrenocorticotropic hormone; B-LPH, beta-lipotropin; NP, N-terminal peptides of pro-opiomelanocortin; Asp, adrenal serine protease.

responsible for cleavage of POMC are called prohormone convertases (PC) and are of two types, $\mathrm{PC} 1$ and $\mathrm{PC} 2$. In the anterior lobe of the pituitary, the action of $\mathrm{PC} 1$ generates the main four POMC-derived peptides: the N-terminal peptide 1-74 (N-POMC 1-74 or pro-gamma-MSH), the joining peptide (JP), ACTH, and beta-lipotrophin ( $\beta$-LPH). In the intermediate lobe, ACTH is cleaved by PC2 to produce alpha-melanocyte-stimulating hormone $(\alpha-\mathrm{MSH})$ and the corticotrophin-like intermediate peptide (CLIP); $\beta$-LPH is completely processed to $\gamma$-LPH and $\beta$-endorphin; and pro-gamma-MSH is cleaved to generate $\gamma 1$ - or $\gamma 3-\mathrm{MSH}$ and N-POMC 1-49. $\gamma 1-\mathrm{MSH}$ is found in humans but not in murines, as the cleavage site (a dibasic residue pair required for processing $\gamma 3-\mathrm{MSH}$ into $\gamma 1-\mathrm{MSH}$ ) is missing in rodents (6). $\gamma$-MSH appears to potentiate the steroidogenic effect of ACTH in the adrenal gland, but the exact form of the peptide $(\gamma 1, \gamma 2$, or $\gamma 3$ ) that produces this effect is still unclear (7). Currently, the concept of tissue-specific cleavage of POMC is acceptable, at least in the adrenal gland, where a serine-protease has been cloned and is responsible for cleaving the pro-gamma-MSH into a 52-residue peptide (8). The family of G-protein-coupled receptors named melanocortin receptors (composed of five members) is responsible for intermediating the action of POMC peptides.

\section{PROLIFERATIVE ADRENAL CORTEX RESPONSES TO ACTH}

The 39-amino acid peptide ACTH is the primary regulator of adrenal gland growth, maintenance, and function. Due to the actions of corticotropin-releasing hormone (CRH), arginine vasopressin, and other secretagogues, ACTH stimulates the pituitary corticotroph cells to release ACTH (9). ACTH binds to specific highaffinity receptors [melanocortin receptor 2 (MC2R)] located on the surface of adrenal cortical cells, stimulating the production of cortisol and corticosterone in murines, which in turn suppresses ACTH-releasing factors. ACTH increases rat adrenal weight by inducing both hyperplasia and hypertrophy in specific zones. In fact, administration of chronic exogenous ACTH in rats induces hyperplasia and hypertrophy in the outer and inner zona fasciculata, respectively (10), and results in a 70\% increase of adrenal mass in rats (11). This phenomenon is also seen in knockout mice for both glucocorticoid and dopamine receptors showing elevated levels of circulating ACTH $(12,13)$. On the other hand, low levels of ACTH, such as those seen in animals submitted to hypophysectomy (14) or treated with dexamethasone (15), result in adrenal atrophy. When adrenal growth occurs to compensate for unilateral adrenalectomy in hypophysectomized rats, neither a decrease in circulating corticosterone nor elevated ACTH levels are observed (16), suggesting the action of neural mediation or other POMC-derived peptides.

\section{MOLECULAR MECHANISMS IMPLICATED IN ACTH ADRENOCORTICAL GROWTH}

Abundant data relating to the signaling triggered by ACTH have been provided by experiments performed in cultured normal and tumoral adrenocortical cells. However, the in vitro action of ACTH on signaling pathways involved with adrenocortical growth is controversial and seems to depend on the cell type, the state of the responding cell, and other environmental signals from extracellular matrices $(17,18)$.

\section{ACTH In Vitro}

In support of the mitogenic or antimitogenic action of $\mathrm{ACTH}$, there are studies analyzing the regulation of ERK/MAPK and related pathways, in different cell types. In quiescent Y1 mouse adrenocortical tumor cells, the molecular mechanisms of cell cycle control comprise two contrasting control pathways for 1-nM ACTH treatment: (1) a mitogenic effect via induction of the fos and jun gene families and weak activation of ERK/MAPK; and (2) a cAMP/PKA-mediated antimitogenic mechanism comprising Akt pathway deactivation, cMyc degradation, and p $27^{\text {Kipl }}$ induction $(17,19,20)$. However, the ability of activate the ERK/MAPK was not interrupted in the cAMP-resistant mutant Y1 cells (Kin-8 cells) stimulated by ACTH, indicating the PKA not mediate the mitogenic action of ACTH (21). Arola and 
collaborators (22) also found an ACTH-inducible biphasic growth effect in rat adrenocortical cells in primary culture, in which a 7-70 nM ACTH-mitogenic effect transduced through the cAMP-mediated system and an ACTH-antimitogenic took place via a cAMP-independent pathway.

In another study performed with Y1 cells, the authors observed the inhibition of ERK/MAPK and c-Jun N-terminal kinases pathways through a PKC and $\mathrm{Ca}^{2+}$-dependent pathway (23), which favors an antimitogenic action of ACTH. In agreement, it was demonstrated by Bey and collaborators (24) that in Y1 cells, MAPK phosphatase- 1 is a component of the ACTH signaling cascade, suggesting that ACTH can downregulate MAPKs. The antimitogenic and pro-apoptotic action of ACTH was reinforced in normal adrenal cells. In rat adrenocortical cells in primary culture, treatment for 3 days with 1-nM ACTH-induced apoptosis, activation of PKA/CREB but not ERK, and expression of c-Fos protein $(25,26)$. Also in support to antimitogenic action of ACTH, in bovine adrenocortical cells, angiotensin II activate MAPK after 5 min of treatment $(\mathrm{EC} 50=0.1 \mathrm{nM})$, whereas ACTH does not stimulate ERK (27). Moreover, in rat adrenal zona glomerulosa cells, ERK activation blocked cell proliferation $(28,29)$.

In another widely used cellular model, the H295 human adrenocortical tumor cell line, which shares similarities with cells of the zona glomerulosa, ACTH stimulates ERK/MAPK signaling. However, in $\mathrm{H} 295$ cells, it has been described that MAPK stimulation by $100-\mathrm{nM}$ ACTH depends on receptor internalization (30). On the other hand, in MC2R-transfected human embryonic kidney cells (31), 1-nM ACTH induces ERK phosphorylation that is partially PKA dependent. However, arrestin-coupled internalization does not involve any level of ACTH-dependent ERK phosphorylation (32). In summary, the analysis of signaling pathways involving the action of ACTH on different cell types and in vitro conditions gives support for an antimitogenic action of ACTH.

\section{ACTH In Vivo}

In research involving depletion of the hypothalamic-pituitaryadrenal (HPA) axis using in vivo models with various approaches such as enucleation-induced adrenal regeneration (33), dexamethasone (Dex) treatment, and hypophysectomy, most but not all of the evidence converges on existing signals and pathways related to a mitogenic effect of ACTH.

Early response genes in the Fos and Jun gene families that form the transcriptional factor AP-1 and stimulate cellular proliferation (34) are induced by both ACTH and FGF2 infused in the rat adrenal gland in situ or in the adrenal cortex of hypophysectomized rats $(35,36)$. In enucleation-induced rat adrenal gland regeneration, the Fos gene was unregulated in the first 2 days of regeneration, while after 5 days of enucleation, downregulation of the Fos and Jun genes was observed (37).

Although it has been proposed that ACTH induces SAPK/ JNK signaling activation and ERK/MAPK inhibition in vivo (23), results of chronic ACTH treatment in Dex-treated rats showed that ACTH is able to induce a sustained and progressive increase in ERK activation and proliferating cell nuclear antigen (PCNA) expression in all adrenal zones (38).
Other findings link the proliferative action of ACTH in Dex-treated rats with regulation of the cyclin-dependent kinase inhibitors (CDKIs) p27Kip1 and p57Kip2 in a time- and sitespecific manner. A study shows that after Dex treatment, most of the cells expressed p27Kip1 but not p57Kip2. Subsequent ACTH treatment suppressed p27Kip1 expression and induced p57Kip2, while PCNA-expressing cells appeared mainly around the zona glomerulosa (39). Other cell-cycle regulators are also implicated in ACTH adrenocortical growth of Dex-treated rats. Besides increasing p27Kip1 expression, inhibition of the HPA axis downregulates cyclin D2 and D3 expression in the adrenal cortex. ACTH increases cyclin E and D3 expression, while it reduces expression of $\mathrm{p} 27 \mathrm{Kip} 1$ protein in the outer and inner fraction preparations of adrenal cortex, respectively $(40,41)$. Moreover, the cell-cycle regulation is time dependent and zone specific. More recently, the Nek2 gene and its protein, together with the Notch gene, have also been shown to be involved in the cell cycle regulation triggered by ACTH (42).

The extracellular matrix (ECM) contributes to the regulation of cell proliferation and cell differentiation and therefore has a role in embryonic development and adult tissue homeostasis. Feige and colleagues have described the composition and expression of ECM components in the adult adrenal gland $(43,44)$. From the periphery to the center of the gland, the authors observed differential expression of fibronectin and laminin, which can be associated with specific activities of the cell components of the zones. However, studies conducted by the Gallo-Payet group show that ECM modulates basal and ACTH-induced cell functions, with fibronectin and collagen I and IV favoring steroid secretion, while laminin promotes proliferation (18). These findings illustrate the importance of the morphological changes associated with ACTH.

Despite the in vivo evidence that ACTH is the only factor that stimulates adrenal growth, other studies point in a different direction. As briefly described above, there are considerable data showing that ACTH inhibited growth of adrenal cells in vitro. In addition, Rao and colleagues (45) showed that rats treated with antiserum against ACTH had significant reduction of blood corticosteroids levels but did not exhibit adrenal atrophy. These and other results, which have been described in comprehensive reviews of the last 60 years of POMC research $(46,47)$, suggest that another factor distinct from ACTH has the ability to promote adrenal growth.

\section{PROLIFERATIVE ADRENAL CORTEX RESPONSES TO N-POMC PEPTIDES}

In 1980, Estivariz and colleagues (48) extracted and purified pro-gamma-MSH from human pituitaries and showed that this peptide could not prevent adrenal atrophy in hypophysectomized rats. However, smaller N-POMC peptides (without the $\gamma 3$-MSH portion) produced by trypsin digestion of pro-gamma-MSH or extracted from pituitary glands proved to be potent mitogens both in vivo and in vitro. In this section, we present information on the proliferative effect of the most important N-POMC peptides. 


\section{N-POMC 1-28}

N-POMC 1-28 was first isolated from human pituitary glands and later characterized as an extraction artifact (49). Even though N-POMC 1-28 is not an endogenous peptide, it has been extensively used to show the mitogenic effect of the N-POMCs. Moreover, the first 28 amino acids of the N-terminal portion of POMC have been shown to be essential to the triggering of adrenal cell proliferation. The mitogenic activity of N-POMC 1-28 has been demonstrated in vivo in murine models $(40,50,51)$ and in vitro in Y1, NCI-H295R, and rat primary culture cells $(26,52$, 53). Peripheral delivery of this peptide in Pomc KO mice does not promote any alterations in the adrenal gland (54) but may prevent atrophy of regenerating adrenal glands after hypophysectomy (55). These findings mean that besides promoting mitosis, this peptide may prevent apoptosis of adrenal cells. Indeed, our group has shown the anti-apoptotic effect of N-POMC 1-28 in adrenal glands of hypophysectomized rats (51). However, the molecular mechanisms underlying this effect are not clear. The positions of two disulfide bridges (between cysteine residues 2-24 and 8-20) seem to be essential to its biological activity (56).

\section{N-POMC 1-49}

N-POMC 1-49 is an endogenous peptide produced and secreted by the intermediary lobe of the pituitary. It is one of the products from the cleavage of pro-gamma-MSH into smaller peptides. In vitro studies have shown that this peptide may promote proliferation of Y1 and NCI-H295R cells $(52,53)$. However, in vivo studies have shown that N-POMC 1-49 does not increase adrenal weight in fetal sheep when infused for $48 \mathrm{~h}$ (57). Interestingly, the presence of an O-linked glycan seems to be crucial for its proliferative effect. However, cleavage of pro-gamma-MSH in the pituitary occurs only if the O-linked glycan is not present in the molecule, resulting in an N-POMC 1-49 without the glycan [reviewed in Bicknell and Lowry (58)]. Clearly, the present data are controversial, and more assays must be done before it can be concluded that N-POMC $1-49$ is the natural N-POMC peptide involved in adrenal proliferation and maintenance.

\section{Pro-Gamma-MSH}

Pro-gamma-MSH is considered to be an active fragment found in the bloodstream at the same levels as ACTH (59). When infused into sheep fetus, this N-POMC peptide increased adrenal weight (57). However, as mentioned before, when administered in hypophysectomized rats, no effect on the adrenal weight was observed (60). Since the mitogenic peptides are located in the N-terminal portion of pro-gamma-MSH, a hypothesis of post-secretional cleavage occurring at the level of specific tissues has emerged. Indeed, Bicknell and collaborators (8) characterized a serine protease they named AsP (adrenal serine protease) that is present in the ECM of adrenal cells and is responsible for cleaving progamma-MSH. The cleavage releases a peptide of 52 residues that induces proliferation of adrenal cortical cells. Moreover, Asp is capable of cleaving small basic substrates (e.g., arginine-arginine, lysine-arginine, etc.), generating N-POMC 1-49. These findings suggest the existence of an endogenous mitogenic N-POMC peptide, but no consensus about its identity has been reached.

\section{THE MOLECULAR MECHANISM INVOLVED IN THE N-POMC PROLIFERATIVE EFFECT}

The proliferative effect of N-POMC peptides has been established since the beginning of the 1980s, but its mechanism has begun to be unveiled only recently. The first study on this topic, conducted by Fassnacht and colleagues (52), concluded that N-POMC 1-28 promotes cell proliferation in NCI-H295R, Y1, and primary cultures of bovine adrenocortical cells by triggering a rapid activation of the ERK/MAPK but not the APK/JNK or p38 pathways. Pepper and Bicknell (53) corroborated those findings and showed that the upstream ERK regulators c-RAF and MEK were activated in $\mathrm{Y} 1$ and NCI-H295R cells treated with N-POMC 1-28 or N-POMC 1-49. In 2011, Mattos and collaborators (26) showed that ERK1/2 was activated in primary cultures of rat adrenocortical cells treated with N-POMC 1-28.

In 2014, we performed a PCR array to evaluate the effect of N-POMC 1-28 on the expression of key genes related to the control of the cell cycle. The genes Nek2 and Notch were upregulated after treatment, suggesting that the proliferative effect of this peptide might be mediated by these genes (42). Additional research is needed to further elucidate the molecular mechanisms involved in the proliferative effect of N-POMC.

A fundamental question that has yet to be definitively answered is the identification of the receptor through which N-POMC peptides elicit their effects on adrenal growth. There have been two unsuccessful attempts to identify such a receptor $(53,58)$. In 2014, we joined efforts with Bicknell's group and proposed a new approach to identifying this receptor. We cloned the most expressed orphan G-protein-coupled receptors in the rat adrenal gland and performed a magnetic cell separation assay using the N-POMC peptide attached to magnetic beads. A likely candidate for the N-POMC receptor was identified, confirmed by ligand-binding assays, and shown to be capable of activating the ERK pathway after stimulation with N-POMC. Further experiments are now been conducted to characterize in vivo and in vitro this potential adrenal N-POMC receptor. Final confirmation of the identity of the adrenal N-POMC receptor is essential for the understanding of cell proliferation in adrenocortical cells.

\section{CONCLUSION}

In this paper, we summarize the current state of knowledge of the roles of ACTH and N-POMC in the proliferation of murine adrenal cells. We identify gaps in knowledge and describe conflicting results that need to be further investigated in order to fully understand the biology of this phenomenon. Examples of such urgently needed studies include gene array assays and pathway analysis to provide more data on the molecular mechanisms triggered by N-POMC peptides as well as to confirm the identity of the natural endogenous mitogenic N-POMC peptide. A holistic and interdisciplinary approach will be required, as none of these peptides or hormones act alone in nature. On the contrary, they trigger a net of responses and activate dozens of pathways 
simultaneously. When we begin to examine this phenomenon from a holistic perspective, we may come to truly understand the proliferative effect of these peptides.

\section{AUTHOR CONTRIBUTIONS}

The authors CL and PM contributed to the conception and design work.

\section{ACKNOWLEDGMENTS}

We would like to thank past and present students from the laboratory who have contributed to the work summarized in this mini-review, in particular Rozana B. F. Baccaro, Gabriele Ebling Mattos, Thompson E. Pavan Torres, and Ismael Cabral Costa.

\section{FUNDING}

CL received funding from Fundação de Amparo à Pesquisa do Estado de São Paulo (Fapesp, the State of São Paulo Research Foundation), from Conselho Nacional de Desenvolvimento Científico e Tecnológico (CNPq, National Council for Scientific and Technological Development), and from Pró-Reitoria de Pesquisa da Universidade de São Paulo (Dean's Office of the University of São Paulo for Research Projects); PM is recipient of a scholarship from FAPESP.

\section{REFERENCES}

1. Whitworth EJ, Kosti O, Renshaw D, Hinson JP. Adrenal neuropeptides: regulation and interaction with ACTH and other adrenal regulators. Microsc Res Tech (2003) 61(3):259-67. doi:10.1002/jemt.10335

2. Hoeflich A, Bielohuby M. Mechanisms of adrenal gland growth: signal integration by extracellular signal regulated kinases1/2. J Mol Endocrinol (2009) 42(3):191-203. doi:10.1677/JME-08-0160

3. Kawauchi H, Takahashi A, Abe K. Gamma-melanotropin is not present in an N-terminal peptide of salmon proopiocortin. Int J Pept Protein Res (1981) 18(3):223-7. doi:10.1111/j.1399-3011.1981.tb02975.x

4. Smith AI, Funder JW. Proopiomelanocortin processing in the pituitary, central nervous system, and peripheral tissues. Endocr Rev (1988) 9(1):159-79. doi:10.1210/edrv-9-1-159

5. Lacaze-Masmonteil T, de Keyzer Y, Luton JP, Kahn A, Bertagna X. Characterization of proopiomelanocortin transcripts in human nonpituitary tissues. Proc Natl Acad Sci U S A (1987) 84(20):7261-5. doi:10.1073/ pnas.84.20.7261

6. Jackson S, Salacinski P, Hope J, Lowry PJ. An investigation of N-terminal pro-opiocortin peptides in the rat pituitary. Peptides (1983) 4(4):431-8. doi:10.1016/0196-9781(83)90045-1

7. Harmer SC, Bicknell AB. Role of gamma-MSH peptides in the regulation of adrenal steroidogenesis. Peptides (2005) 26(10):1944-51. doi:10.1016/j. peptides.2004.11.028

8. Bicknell AB, Lomthaisong $\mathrm{K}$, Woods RJ, Hutchinson EG, Bennett HP, Gladwell RT, et al. Characterization of a serine protease that cleaves pro-gamma-melanotropin at the adrenal to stimulate growth. Cell (2001) 105(7):903-12. doi:10.1016/S0092-8674(01)00403-2

9. Watanabe T, Oki Y, Ort DN. Kinetic actions and interactions of arginine vasopressin, angiotensin-II, and oxytocin on adrenocorticotropin secretion by rat anterior pituitary cells in the microperifusion system. Endocrinology (1989) 125(4):1921-31. doi:10.1210/endo-125-4-1921

10. Ulrich-Lai YM, Figueiredo HF, Ostrander MM, Choi DC, Engeland WC, Herman JP. Chronic stress induces adrenal hyperplasia and hypertrophy in a subregion-specific manner. Am JPhysiol Endocrinol Metab (2006) 291(5):E965-73. doi:10.1152/ajpendo.00070.2006

11. Nussdorfer GG, Rebuffat P, Mazzocchi G, Belloni AS, Meneghelli V. Investigations on adrenocortical mitochondria turnover. I. Effect of chronic treatment with ACTH on the size and number of rat zona fasciculada mitochondria. Cell Tissue Res (1974) 150(1):79-94.

12. Cole TJ, Blendy JA, Monaghan AP, Krieglstein K, Schmid W, Aguzzi A, et al. Targeted disruption of the glucocorticoid receptor gene blocks adrenergic chromaffin cell development and severely retards lung maturation. Genes Dev (1995) 9(13):1608-21. doi:10.1101/gad.9.13.1608

13. Saiardi A, Borrelli E. Absence of dopaminergic control on melanotrophs leads to Cushing's-like syndrome in mice. Mol Endocrinol (1998) 12(8):1133-9. doi: $10.1210 /$ me.12.8.1133

14. Jones IC, Roby CC. Some aspects of zonation and function of the adrenal cortex. I. The effects of hypophysectomy on the adrenal cortex of the adult male mouse. J Endocrinol (1954) 10(3):245-50. doi:10.1677/joe.0.0100266

15. Wright NA, Appleton D. The action of dexamethasone on the adrenal cortex. J Endocrinol (1972) 53(3):xxxvii.

16. Engeland WC, Shinsako J, Dallman MF. Corticosteroids and ACTH are not required for compensatory adrenal growth. Am J Physiol (1975) 229(5):1461-4.

17. Rocha KM, Forti FL, Lepique AP, Armelin HA. Desconstructing the molecular mechanism of cell cycle control in a mouse adrenocortical cell line: roles of ACTH. Microsc Res Tech (2003) 61(3):268-74. doi:10.1002/ jemt. 10336

18. Otis M, Campbell S, Payet MD, Gallo-Payet N. Expression of extracellular matrix proteins and integrins in rat adrenal gland: importance for ACTHassociated functions. J Endocrinol (2007) 193(3):331-47. doi:10.1677/ JOE-07-0055

19. Lotfi CF, Todorovic Z, Armelin HA, Schimmer BP. Unmasking a growth-promoting effect of the adrenocorticotropic hormone in Y1 mouse adrenocortical tumor cells. J Biol Chem (1997) 272(47):29886-91. doi:10.1074/ jbc. 272.47 .29886

20. Lotfi CF, Armelin HA. c-Fos protein is a mediator in mitogenic response to ACTH. Endocr Res (1998) 24(3-4):421-4. doi:10.3109/07435809809032626

21. LeT, Schimmer BP. The regulation of MAPKs in Y1 mouse adrenocortical tumor cells. Endocrinology (2001) 142(10):4282-7. doi:10.1210/endo.142.10.8441

22. Arola J, Heikkilä P, Kahri AI. Biphasic effect of ACTH on growth of rat adrenocortical cells in primary culture. Cell Tissue Res (1993) 271(1):169-76. doi:10.1007/BF00297555

23. Watanabe G, Pena P, Albanese C, Wilsbacher LD, Young JB, Pestell RG. Adrenocorticotropin induction of stress-activated protein kinase in the adrenal cortex in vivo. J Biol Chem (1997) 272(32):20063-9. doi:10.1074/ jbc.272.32.20063

24. Bey P, Gorostizaga AB, Maloberti PM, Lozano RC, Poderoso C, Cornejo Maciel F, et al. Adrenocorticotropin induces mitogen-activated protein kinase phosphatase 1 in Y1 mouse adrenocortical tumor cells. Endocrinology (2003) 144(4):1399-406. doi:10.1210/en.2002-220987

25. Mattos GE, Lotfi CF. Differences between the growth regulatory pathways in primary rat adrenal cells and mouse tumor cell line. Mol Cell Endocrinol (2005) 245(1-2):31-42. doi:10.1016/j.mce.2005.10.001

26. Mattos GE, Jacysyn JF, Amarante-Mendes GP, Lotfi CF. Comparative effect of FGF2, synthetic peptides 1-28 N-POMC and ACTH on proliferation in rat adrenal cell primary cultures. Cell Tissue Res (2011) 345(3):343-56. doi:10.1007/s00441-011-1220-8

27. Chabre O, Cornillon F, Bottari SP, Chambaz EM, Vilgrain I. Hormonal regulation of mitogen-activated protein kinase activity in bovine adrenocortical cells: cross-talk between phosphoinositides, adenosine 3',5'-monophosphate, and tyrosine kinase receptor pathways. Endocrinology (1995) 136(3):956-64. doi:10.1210/en.136.3.956

28. Otis M, Campbell S, Payet MD, Gallo-Payet N. Angiotensin II stimulates protein synthesis and inhibits proliferation in primary cultures of rat adrenal glomerulosa cells. Endocrinology (2005) 146(2):633-42. doi:10.1210/ en.2004-0935

29. Otis M, Gallo-Payet N. Role of MAPKs in angiotensin II-induced steroidogenesis in rat glomerulosa cells. Mol Cell Endocrinol (2007) 265-266:126-30. doi:10.1016/j.mce.2006.12.008 
30. Janes ME, Chu KM, Clark AJ, King PJ. Mechanisms of adrenocorticotropininduced activation of extracellularly regulated kinase $1 / 2$ mitogen-activated protein kinase in the human H295R adrenal cell line. Endocrinology (2008) 149(4):1898-905. doi:10.1210/en.2007-0949

31. Sebag JA, Hinkle PM. Regulation of G protein-coupled receptor signaling: specific dominant-negative effects of melanocortin 2 receptor accessory protein 2. Sci Signal (2010) 3(116):ra28. doi:10.1126/scisignal.2000593

32. Roy S, Roy SJ, Pinard S, Taillefer LD, Rached M, Parent JL, et al. Mechanisms of melanocortin-2 receptor (MC2R) internalization and recycling in human embryonic kidney (hek) cells: identification of Key Ser/Thr (S/T) amino acids. Mol Endocrinol (2011) 25(11):1961-77. doi:10.1210/me.2011-0018

33. Holzwarth MA, Shinsako J, Dallman MF. Adrenal regeneration. Time course, effect of hypothalamic hemi-islands and response to unilateral adrenalectomy. Neuroendocrinology (1980) 31(3):168-76. doi:10.1159/000123069

34. Angel P, Karin M. The role of Jun, Fos and the AP-1 complex in cell-proliferation and transformation. Biochim Biophys Acta (1991) 1072(2-3):129-57.

35. Baccaro RB, Mendonça PO, Torres TE, Lotfi CF. Immunohistochemical Jun/ Fos protein localization and DNA synthesis in rat adrenal cortex after treatment with ACTH or FGF2. Cell Tissue Res (2007) 328(1):7-18. doi:10.1007/ s00441-006-0352-8

36. Torres TE, Lotfi CF. Distribution of cells expressing Jun and Fos proteins and synthesizing DNA in the adrenal cortex of hypophysectomized rats: regulation by ACTH and FGF2. Cell Tissue Res (2007) 329(3):443-55. doi:10.1007/ s00441-007-0436-0

37. Tyczewska M, Rucinski M, Ziolkowska A, Szyszka M, Trejter M, Hochol-Molenda A, et al. Enucleation-induced rat adrenal gland regeneration: expression profile of selected genes involved in control of adrenocortical cell proliferation. Int J Endocrinol (2014) 2014:130359. doi:10.1155/2014/130359

38. Ferreira JG, Cruz C, Vinson GP, Pignatelli D. ACTH modulates ERK phosphorylation in the adrenal gland in a time-dependent manner. Endocr Res (2007) 30(4):661-6. doi:10.1081/ERC-200043952

39. Kobayashi H, Kambe F, Imai T, Hibi Y, Kikumori T, Ohmori S, et al. Differential expression of cyclin-dependent kinase inhibitors, p27Kip1 and p57Kip2, by corticotropin in rat adrenal cortex. J Endocrinol (2006) 189(3):671-9. doi:10.1677/joe.1.06419

40. Mendonça PO, Lotfi CF. The proliferative effect of synthetic N-POMC(1-28) peptides in rat adrenal cortex: a possible role for cyclin E. Mol Cell Endocrinol (2011) 336(1-2):156-61. doi:10.1016/j.mce.2010.12.012

41. de Mendonca PO, Liria CW, Machini MT, Lotfi CF. N-POMC1-28 increases cyclin D expression and inhibits P27(kip1) in the adrenal cortex. Mol Cell Endocrinol (2013) 371(1-2):166-73. doi:10.1016/j.mce.2012.11.017

42. de Mendonca PO, Costa IC, Lotfi CF. The involvement of Nek2 and Notch in the proliferation of rat adrenal cortex triggered by POMC-derived peptides. PLoS One (2014) 9(10):e108657. doi:10.1371/journal.pone.0108657

43. Pellerin S, Keramidas M, Chambaz EM, Feige JJ. Expression of laminin and its possible role in adrenal cortex homeostasis. Endocrinology (1997) 138(3):1321-7. doi:10.1210/en.138.3.1321

44. Feige JJ, Keramidas M, Chambaz EM. Hormonally regulated components of the adrenocortical cell environment and the control of adrenal cortex homeostasis. Horm Metab Res (1998) 30(6-7):421-5. doi:10.1055/s-2007-978908 Review

45. Rao AJ, Long JA, Ramachandran J. Effects of antiserum to adrenocorticotropin on adrenal growth and function. Endocrinology (1978) 102(2):371-8. doi:10.1210/endo-102-2-371

46. Lowry P. 60 years of POMC: purification and biological characterisation of melanotrophins and corticotrophins. J Mol Endocrinol (2015). doi:10.1530/ JME-15-0260
47. Bicknell AB. N-terminal POMC peptides and adrenal growth. J Mol Endocrinol (2016). doi:10.1530/JME-15-0269

48. Estivariz FE, Hope J, McLean C, Lowry PJ. Purification and characterization of a gamma-melanotropin precursor from frozen human pituitary glands. Biochem J (1980) 191(1):125-32. doi:10.1042/bj1910125

49. McLean C, Hope J, Salacinski P, Estivariz F, Lowry PJ. Purification and characterization of amino-terminal pro-opiocortin peptides from human pituitary glands. Biosci Rep (1981) 1(11):843-9. doi:10.1007/BF01114817

50. Lowry PJ, Silas L, McLean C, Linton EA, Estivariz FE. Pro-gamma-melanocytestimulating hormone cleavage in adrenal gland undergoing compensatory growth. Nature (1983) 306(5938):70-3. doi:10.1038/306070a0

51. Torres TE, de Mendonça PO, Lotfi CF. Synthetic modified N-POMC(1-28) controls in vivo proliferation and blocks apoptosis in rat adrenal cortex. Cell Tissue Res (2010) 341(2):239-50. doi:10.1007/s00441-010-0998-0

52. Fassnacht M, Hahner S, Hansen IA, Kreutzberger T, Zink M, Adermann K, et al. N-terminal proopiomelanocortin acts as a mitogen in adrenocortical tumor cells and decreases adrenal steroidogenesis. J Clin Endocrinol Metab (2003) 88(5):2171-9. doi:10.1210/jc.2002-021318

53. Pepper DJ, Bicknell AB. The stimulation of mitogenic signaling pathways by N-POMC peptides. Mol Cell Endocrinol (2009) 300(1-2):77-82. doi:10.1016/j. mce.2008.09.021

54. Coll AP, Fassnacht M, Klammer S, Hahner S, Schulte DM, Piper S, et al. Peripheral administration of the N-terminal pro-opiomelanocortin fragment 1-28 to Pomc-/- mice reduces food intake and weight but does not affect adrenal growth or corticosterone production. J Endocrinol (2006) 190(2):515-25. doi:10.1677/joe.1.06749

55. Estivariz FE, Carino M, Lowry PJ, Jackson S. Further evidence that N-terminal pro-opiomelanocortin peptides are involved in adrenal mitogenesis. J Endocrinol (1988) 116(2):201-6. doi:10.1677/joe.0.1160201

56. DenefC, Roudbaraki M, Van Bael A. Growth and differentiation factors derived from the N-terminal domain of pro-opiomelanocortin. Clin Exp Pharmacol Physiol (2001) 28(3):239-43. doi:10.1046/j.1440-1681.2001.03421.x

57. Ross JT, Bennett HP, James S, McMillen IC. Infusion of $\mathrm{N}$-proopiomelanocortin-(1-77) increases adrenal weight and messenger ribonucleic acid levels of cytochrome P450 17alpha-hydroxylase in the sheep fetus during late gestation. Endocrinology (2000) 141(6):2153-8. doi:10.1210/ en.141.6.2153

58. Bicknell AB, Lowry PJ. Adrenal growth is controlled by expression of specific pro-opiomelanocortin serine protease in the outer adrenal cortex. Endocr Res (2002) 28(4):589-95. doi:10.1081/ERC-120016971

59. Chan JS, Seidah NG, Chrétien M. Measurement of N-terminal (1-76) of human proopiomelanocortin in human plasma: correlation with adrenocorticotropin. J Clin Endocrinol Metab (1983) 56(4):791-6. doi:10.1210/jcem-56-4-791

60. Estivariz FE, Iturriza F, McLean C, Hope J, Lowry PJ. Stimulation of adrenal mitogenesis by N-terminal proopiocortin peptides. Nature (1982) 297(5865):419-22. doi:10.1038/297419a0

Conflict of Interest Statement: The authors declare that the research was conducted in the absence of any commercial or financial relationships that could be construed as a potential conflict of interest.

Copyright (C) 2016 Lotfi and de Mendonca. This is an open-access article distributed under the terms of the Creative Commons Attribution License (CC BY). The use, distribution or reproduction in other forums is permitted, provided the original author(s) or licensor are credited and that the original publication in this journal is cited, in accordance with accepted academic practice. No use, distribution or reproduction is permitted which does not comply with these terms. 